\title{
KATARZYNA LeŚKIEWICZ
}

ORCID: 0000-0001-5261-2752

\section{Prawne aspekty włączenia w zakres polityki klimatyczno-energetycznej emisji i pochłaniania gazów cieplarnianych w wyniku działalności związanej z użytkowaniem gruntów, zmianą użytkowania gruntów i leśnictwem}

\section{Wprowadzenie}

Artykuł porusza kwestię prawnych aspektów włączenia w zakres polityki klimatyczno-energetycznej emisji i pochłaniania gazów cieplarnianych w wyniku działalności związanej z użytkowaniem gruntów, zmianą użytkowania gruntów i leśnictwem ${ }^{1}$. Zagadnienie wskazane w tytule wiąże się z problematyką ochrony klimatu, której dotyczy regulacja „zarządzania unią energetyczną”. Według rozporządzenia nr 2018/1999 unia energetyczna powinna obejmować pięć wymiarów: bezpieczeństwo energetyczne, wewnętrzny rynek energii, efektywność energetyczną, obniżenie emisyjności oraz badania naukowe, innowacje i konkurencyjność 2 . Celem unii energetycznej w sferze klimatu jest zapewnienie unijnym konsumentom (w tym gospodarstwom domowym i przedsiębiorstwom)

${ }^{1}$ Por. Forest governance and climate-change mitigation, Published by FAO and ITTO 2009, http://www.fao.org/forestry/19488-0a2b1be34bcc2f24f780036ed0c5f9d69.pdf [dostęp: 21.09.2018].

${ }^{2}$ Art. 1 ust. 2 Rozporządzenia Parlamentu Europejskiego i Rady (UE) 2018/1999 z dnia 11 grudnia 2018 r. w sprawie zarządzania unią energetyczną i działaniami w dziedzinie klimatu, zmiany rozporządzeń Parlamentu Europejskiego i Rady (WE) nr 663/2009 i (WE) nr 715/2009, dyrektyw Parlamentu Europejskiego i Rady 94/22/WE, 98/70/WE, 2009/31/WE, 2009/73/WE, 2010/31/UE, 2012/27/UE i 2013/30/UE, dyrektyw Rady 2009/119/WE i (EU) 2015/652 oraz 
bezpiecznych, zrównoważonych, konkurencyjnych i niedrogich dostaw energii oraz pobudzanie badań naukowych i innowacji, wynikające z potrzeby zachowania, ochrony i poprawy jakości środowiska, a także wspierania racjonalnego wykorzystywania zasobów naturalnych. $\mathrm{Z}$ kolei priorytetem mechanizmu zarządzania unią energetyczną powinno być umożliwienie osiągnięcia celów unii energetycznej, a zwłaszcza polityki klimatyczno-energetycznej do $2030 \mathrm{r}$. w zakresie ograniczenia emisji gazów cieplarnianych, energii ze źródeł odnawialnych i efektywności energetycznej ${ }^{3}$. Wskazana regulacja ma zatem służyć łagodzeniu zmian klimatu w skali światowej.

W politykę kilmatyczno-energetyczną włączono kwestie emisji i pochłaniania związanego z gruntami, a zagadnienia te uregulowało rozporządzenie nr 2018/841 (zwane w skrócie „LULUCF”4) oraz rozporządzenie w sprawie wspólnego wysiłku redukcyjnego (dalej jako „ESR”), które określa roczne cele redukcji emisji gazów cieplarnianych dla poszczególnych państw członkowskich na lata 2021-2030. W rozporządzeniu LULUCF uwzględniono zobowiązanie Unii Europejskiej na lata 2021-2030 do osiągnięcia zerowych emisji netto z sektora objętego tą regulacją. Akt ten dotyczy wszystkich gruntów zagospodarowanych, w tym lasów, użytków rolnych, użytków zielonych oraz (do 2026 r.) terenów podmokłych, i ustanawia nowy unijny proces zarządzania monitorowaniem procesu obliczania przez państwa członkowskie emisji i pochłaniania GHG z działalności w lasach.

uchylenia rozporządzenia Parlamentu Europejskiego i Rady (UE) nr 525/2013 (Dz.Urz. L 328/1, s. 1 z 21 grudnia 2018 r.), dalej zwane rozporządzeniem nr 2018/1999.

${ }^{3}$ Pkt 2, 3 i 18 preambuły rozporządzenia nr 2018/1999.

${ }^{4}$ Rozporządzenie Parlamentu Europejskiego i Rady (UE) 2018/841 w sprawie włączenia emisji i pochłaniania gazów cieplarnianych w wyniku działalności związanej z użytkowaniem gruntów, zmianą użytkowania gruntów i leśnictwem do ram polityki klimatyczno-energetycznej do roku 2030 i zmieniające rozporządzenie (UE) nr 525/2013 oraz decyzję $\mathrm{nr}$ 529/2013/UE (Dz.U. L 156 z 19.6.2018, s. 1), dalej zwane rozporządzeniem nr 2018/841 lub rozporządzeniem LULUCF (skrót LULUCF pochodzi z ang. Land Use, Land Use Change and Forestry). Por. także N. Forsell, A. Korosuo, S. Federici, M. Gusti, J.-J. Rincón-Cristóbal, S. Rüter, B. Sánchez-Jiménez, C. Dore, O. Brajterman, J. Gardiner, Guidance on developing and reporting the Forest Reference Levels in accordance with Regulation (EU) 2018/841, https://ec.europa.eu/ clima/policies/forests/lulucf_en [dostęp: 15.09.2019]; H. Böttcher, C. Zell-Ziegler, A. Herold, A. Siemons, EU LULUCF Regulation explained Summary of core provisions and expected effects, Berlin, 21.06.2019, https://www.oeko.de/fileadmin/oekodoc/Analysis-of-LULUCF-Regulation. pdf [dostęp: 20.09.2019].

5 Rozporządzenie Parlamentu Europejskiego i Rady (UE) 2018/842 z dnia 30 maja 2018 r. w sprawie wiążących rocznych redukcji emisji gazów cieplarnianych osiąganych przez państwa członkowskie od 2021 r. do 2030 r. przyczyniających się do działań w dziedzinie klimatu w celu wywiązania się z zobowiązań wynikających z Porozumienia paryskiego oraz zmieniające rozporządzenie (UE) nr 525/2013 (Dz.U. L 156 z 19.6.2018, s. 26), dalej zwane rozporządzeniem nr 2018/842. 
Wskazaną tematyką nie zajmowano się dotąd w literaturze prawniczej. Niektóre wątki związane z ochroną klimatu pojawiły się w pracach o charakterze podręcznikowym, a także $\mathrm{w}$ publikacjach zagranicznych ${ }^{6}$ oraz $\mathrm{w}$ literaturze nauk leśnych? ${ }^{7}$.

Zasadność podjęcia badań na ten temat potwierdzają najbardziej aktualne wyniki analiz stanu środowiska, przedstawione choćby w opublikowanym w marcu 2019 r. szóstym raporcie GEO (tj. „Global Environment Outlook”) w którym zawarto szczegółowe informacje na temat stanu środowiska naturalnego. Hasłem głównym raportu jest „Zdrowa planeta, zdrowi ludzie” (,Healthy planet, healthy people"), a jako podstawowe zagrożenia wskazuje się zmiany klimatyczne, zanieczyszczenie powietrza, urbanizację, marnotrawstwo żywności i zasobów naturalnych, degradację gleby, zanik bioróżnorodności.

Z kolei według Raportu UNEP z 2017 r. w sprawie rozbieżności między potrzebami a perspektywami w zakresie redukcji emisji ${ }^{9}$ kraje G-20 (generujące około 3/4 globalnych emisji gazów cieplarnianych) mogą łącznie wypełnić te zobowiązania, przy czym szacuje się, że Unia Europejska powinna to zrobić bez żadnej kompensacji międzynarodowej, podobnie jak Chiny, Indie i Japonia. Australia, Brazylia i Rosja są również zobowiązane zastosować się do postanowień raportu ${ }^{10}$. Intensywność emisji gazów cieplarnianych z UE

${ }^{6}$ Por. np. M. Górski (red.), Prawo ochrony środowiska, Warszawa 2018, s. 290-293; A. Bolte, Adaptive forest management in central Europe: Climate change impacts, strategies and integrative concept, „Scandinavian Journal of Forest Research” 2009, Vol. 24, Issue 6, http://dx.doi. org/10.1080/02827580903418224 [dostęp: 01.10.2017]; M. Lindner, T. Suominen, Towards a sustainable bioeconomy, ,Scandinavian Journal of Forest Research” 2017, vol. 32(7), s. 549-550, http:// dx.doi.org/10.1080/02827581.2017.1288826 [dostęp: 01.10.2017]; L. Palloni, Il ruolo delle foreste nella lotta al global warming e la sostenibilità ambientale: il caso del Canada, w: Studi in onore di Luigi Costato volume primo. Diritto Agrario e Agroambientale, Napoli 2014, s. 463-474; Narodowy Program Leśny. Synteza, Programy, wprowadzenia, podsumowania i rekomendacje ośmiu paneli ekspertów: klimat, wartość, dziedzictwo, ochrona, rozwój, organizacja, współdziałanie, nauka, Sękocin Stary, 18 czerwca 2013 - 8 grudnia 2015 roku, oprac. K. Rykowski, Instytut Badawczy Leśnictwa 2016, s. 170, http://www.npl.ibles.pl/sites/default/files/synteza.pdf, [dostęp: 14.07.2017].

${ }^{7}$ Por. A. Kaliszewski, Cele polityki leśnej w Polsce w świetle aktualnych priorytetów leśnictwa w Europie Część 1. Procesy kształtujące politykę leśna w Europie, „Leśne Prace Badawcze” 2018, Vol. 79 (1): 77-87, DOI: 10.2478/frp-2018-0009.

${ }^{8}$ Raport sporządzony z inicjatywy Programu Narodów Zjednoczonych ds. Środowiska (ang. United Nations Environment Programme, UNEP) i opublikowany podczas szczytu ONZ ds. środowiska w Nairobi (Kenia), https://www.unenvironment.org/resources/global-environment-outlook-6 [dostęp: 30.08.2019].

${ }^{9}$ https://wedocs.unep.org/handle/20.500.11822/22070 [dostęp: 10.06.2019].

10 Sprawozdanie Komisji dla Parlamentu Europejskiego i Rady UE i porozumienie klimatyczne z Paryża: podsumowanie postępów na konferencji COP w Katowicach wymagane na podstawie art. 21 rozporzadzenia Parlamentu Europejskiego i Rady (UE) nr 525/2013 z dnia 21 maja 2013 w sprawie mechanizmów monitorowania i sprawozdawczości w zakresie emisji 
w przeliczeniu na PKB prawdopodobnie pozostanie najniższa w grupie G-20 do 2030 r. ${ }^{11}$ Jednak utrzymanie globalnego ocieplenia na poziomie znacznie poniżej $2^{\circ} \mathrm{C}$ (lub $1,5^{\circ} \mathrm{C}$ ) wymaga przyśpieszenia dekarbonizacji przez kraje o silnych, dużych gospodarkach ze stale rosnącym poziomem emisji gazów cieplarnianych.

UE wyznaczyła cele dotyczące stopniowego ograniczenia emisji gazów cieplarnianych do 2050 r., które ujęte zostały w pakiecie klimatyczno-energetycznym do roku 2020 oraz ramach polityki klimatyczno-energetycznej do roku 2030. Zakładają one przejście na gospodarkę emisyjną do 2050 r. Pakiet 2020 stanowi zbiór wiążących przepisów, które mają zagwarantować, że UE osiągnie swoje cele w zakresie klimatu i energii do 2020 r. Wśród tych celów chodzi o ograniczenie o $20 \%$ emisji gazów cieplarnianych (w stosunku do poziomu z 1990 r.), dwudziestoprocentowy udział energii ze źródeł odnawialnych w całkowitym zużyciu energii w UE, zwiększenie o $20 \%$ efektywności energetycznej. Realizacja tych celów przebiegać ma w kilku obszarach.

Gdy chodzi o realizację dotychczasowych zobowiązań, w 2017 r. wielkość emisji dla większości państw członkowskich była mniejsza niż ich roczne limity emisji. W przypadku dziewięciu państw (Grecja, Słowacja, Chorwacja, Rumunia, Węgry, Portugalia, Szwecja, Niderlandy i Słowenia) wielkość emisji była mniejsza od limitu o co najmniej 10 p.p. ${ }^{12}$ Natomiast, według szacunków, Malta, Niemcy, Irlandia, Austria, Cypr, Polska i Finlandia przekroczyły swoje roczne limity emisji, podobnie jak Bułgaria, Estonia i Litwa, ale o mniej niż 1 p.p. ${ }^{13}$

Prognozy wskazują, że państwom takim, jak Estonia, Łotwa, Finlandia, Niemcy, Litwa, Austria, Rumunia, Polska i Hiszpania, przy zastosowaniu obecnych strategii, zabraknie ponad 10 p.p. do osiągnięcia celów na 2030 r. Wszystkie

gazów cieplarnianych oraz zgłaszania innych informacji na poziomie krajowym i unijnym, majacych znaczenie dla zmiany klimatu oraz uchylającego decyzję $n r$ 280/2004/WE, \{SWD (2018) 453 final\}, Bruksela, 26.10.2018, $\operatorname{COM}(2018) 716$ final, https://eur-lex.europa.eu/legal-content/ $\mathrm{PL} / \mathrm{TXT} /$ ?uri=CELEX\%3A52018DC0716 [dostęp: 10.06.2019].

${ }^{11}$ Raport z $2016 r$ r. w sprawie rozbieżności między potrzebami a perspektywami $w$ zakresie redukcji emisji: sprawozdanie podsumowujace UNEP: https://europa.eu/capacity4dev/unep/document/emissions-gap-report-2016-unep-synthesis-report [dostęp: 10.06.2019].

12 Punkty procentowe reprezentują różnicę między wielkością emisji a rocznym limitem emisji wyrażoną jako zmiana procentowa w stosunku do emisji w roku bazowym 2005.

${ }_{13}$ Sprawozdanie Komisji dla Parlamentu Europejskiego i Rady UE i porozumienie klimatyczne z Paryża: podsumowanie postępów na konferencji COP w Katowicach wymagane na podstawie art. 21 rozporzadzenia Parlamentu Europejskiego i Rady (UE) nr 525/2013 z dnia 21 maja 2013 w sprawie mechanizmów monitorowania i sprawozdawczości $w$ zakresie emisji gazów cieplarnianych oraz zgłaszania innych informacji na poziomie krajowym i unijnym, majacych znaczenie dla zmiany klimatu oraz uchylajacego decyzję $n r$ 280/2004/WE, \{SWD (2018) 453 final\}, Bruksela, 26.10.2018, COM(2018)716 final, https://eur-lex.europa.eu/legal-content/ PL/TXT/?uri=CELEX\%3A52018DC0716 [dostęp: 10.06.2019]. 
państwa członkowskie, które prognozują niezrealizowanie tych celów, winny określić w swoich krajowych planach klimatyczno-energetycznych (na podstawie rozporządzenia w sprawie zarządzania unią energetyczną), w jaki sposób będą dążyć do wypełnienia swoich zobowiązań.

Czy obowiązujące regulacje prawne mogą być ocenione jako sprzyjające realizacji założonych celów unii energetycznej w zakresie zarządzania gruntami leśnymi? Czy przyjęte przez Polskę w Krajowym Planie Rozliczeń dla Leśnictwa ${ }^{14}$ rozwiązania można uznać za sprzyjające osiągnięciu założeń rozporządzenia LULUCF? Aby odpowiedzieć na te pytania, należy przyjrzeć się unijnej regulacji LULUCF, a także krajowemu planowi klimatyczno-energetycznemu i krajowemu planowi rozliczeń dla leśnictwa.

\section{Unijne ramy prawne}

Na szczeblu UE ochrona i poprawa środowiska znajduje wyraz w art. 11 czy art. 191 TFUE $^{15}$. Realizacja przyjętych założeń wiąże się z obowiązkiem krajów członkowskich stworzenia zintegrowanych krajowych planów w dziedzinie energii i klimatu, które winny być zgodne z wyznaczonymi przez Organizację Narodów Zjednoczonych celami zrównoważonego rozwoju. Efektem ma być utrzymanie wzrostu średniej temperatury na świecie znacznie poniżej $2^{\circ} \mathrm{C} w$ stosunku do poziomu sprzed epoki przemysłowej oraz dążenie do ograniczenia tego wzrostu do $1,5^{\circ} \mathrm{C}$ powyżej poziomu sprzed epoki przemysłowej, a także osiągnięcie długoterminowej redukcji emisji gazów cieplarnianych i większego pochłaniania emisji przez pochłaniacze we wszystkich sektorach ${ }^{16}$. Wiadomo, że głównym czynnikiem antropogenicznym globalnego wzrostu temperatury jest gromadzenie się gazów cieplarnianych w atmosferze.

Procesy pochłaniające gazy cieplarniane z atmosfery zwane są ,pochłaniaczami”, zaś procesy uwalniające gazy cieplarniane do atmosfery, takie jak spalanie paliw, to „źródła”.

Według rozporządzenia LULUCF (art. 3 ust. 1 - odpowiednio pkt 1, 2, 3) „pochłaniacz” oznacza dowolny proces, działalność lub mechanizm które pochłaniają z atmosfery gaz cieplarniany, aerozol lub prekursor gazu cieplarnianego,

${ }^{14}$ Krajowy Plan Rozliczeń dla Leśnictwa opracowany przez Zespót do spraw opracowania krajowych planów zwiąanych z rozliczaniem emisji i pochłaniania gazów cieplarnianych $w$ wyniku działalności zwiąanej z leśnictwem, Warszawa 2018 (dalej jako: KPRL), https://bip.mos.gov.pl/ fileadmin/user_upload/bip/strategie_plany_programy/Krajowy_Plan_Rozliczen_dla_Lesnictwa/ NFAP_2018_POLAND_PL_FINAL.pdf, s. 13 [dostęp: 09.09.2019].

${ }_{15}$ Traktat o funkcjonowaniu Unii Europejskiej, Dz.U. z 2004 r. nr 90, poz. 864/2.

${ }^{16}$ Pkt 36 i 37 preambuły rozporządzenia nr 2018/2019. 
natomiast „Źródło” oznacza dowolny proces, działalność lub mechanizm, które uwalniają do atmosfery gaz cieplarniany, aerozol lub prekursor gazu cieplarnianego. Z kolei „rezerwuar węgla” oznacza całość lub część elementu lub systemu biogeochemicznego na terytorium państwa członkowskiego, w którym przechowywane są węgiel pierwiastkowy, dowolny prekursor gazu cieplarnianego zawierający węgiel lub dowolny gaz cieplarniany zawierający węgiel. Najważniejszymi pochłaniaczami są oceany i biomasa na lądzie. Suma źródeł i pochłaniaczy daje wynik emisji netto. Główne antropogeniczne gazy cieplarniane obejmują dwutlenek węgla $\left(\mathrm{CO}_{2}\right)$, metan $\left(\mathrm{CH}_{4}\right)$ oraz tlenek diazotu $\left(\mathrm{N}_{2} \mathrm{O}\right)$. W rozporządzeniu LULUCF wszystkie gazy cieplarniane zostały wyrażone pod postacią ekwiwalentu $\mathrm{CO}_{2}$ (wpływ masy ekwiwalentu $\mathrm{CO}_{2} \mathrm{w}$ atmosferze na wymuszanie promieniowania słonecznego $)^{17}$. W sektorze LULUCF największym ,pochłaniaczem” są grunty leśne, szacowana wielkość pochłaniania $\mathrm{CO}_{2}$ generowana jest w głównej mierze przez przyrost biomasy żywej ${ }^{18}$. Dlatego uprawnione jest stwierdzenie, że prawna regulacja udziału lasów w ochronie klimatu może mieć niebagatelne znaczenie dla osiągania rezultatów zakładanych przez UE.

Jak wspomniano, w politykę klimatyczno-eneregetyczną włączony został sektor użytkowania gruntów, zmiany użytkowania gruntów i leśnictwa (LULUCF). Jest on bowiem narażony na skutki zmian klimatu $z$ jednej strony, a z drugiej może przyczynić się do łagodzenia tych zmian. Grunty w UE przechowują więcej emisji niż wydzielają, a rozporządzenie LULUCF skupia się na tworzeniu zachęt co najmniej do utrzymania tej sytuacji. W świetle omawianej regulacji każde państwo członkowskie musi zapewnić, aby emisje gazów cieplarnianych z użytkowania gruntów były całkowicie równoważone pochłanianiem $\mathrm{CO}_{2} \mathrm{z}$ atmosfery poprzez działanie w tym sektorze. Proces ten podporządkowany został tzw. zasadzie „zerowego salda”, w myśl której konieczne jest kompensowanie emisji pochodzących z wylesiania, na przykład poprzez zapewnienie równoważnych pochłaniaczy dwutlenku węgla $\mathrm{z}$ zalesiania lub poprawy zrównoważonego zarządzania istniejącymi lasami.

Najważniejszym zobowiązaniem państw członkowskich określonym w rozporządzeniu LULUCF (art. 4) jest, by w okresach od 2021 r. do 2025 r. oraz od 2026 r. do 2030 r., z uwzględnieniem mechanizmów elastyczności przewidzianych w art. 12 i 13 tego aktu, każde państwo członkowskie zapewniło, aby emisje nie przewyższały pochłaniania, co oblicza się jako sumę całkowitych emisji i całkowitego pochłaniania na jego terytorium łącznie we wszystkich kategoriach rozliczania gruntów, zgodnie z przywołanym rozporządzeniem. W rozliczeniach tych emisje oznaczać się winno znakiem dodatnim

${ }^{17}$ KPRL, s. 13.

${ }^{18}$ Ibidem, s. 14. 
$(+)$, a pochłanianie - znakiem ujemnym (-). Każde państwo członkowskie ma obowiązek przygotować i prowadzić rachunki rozliczeniowe prawidłowo odzwierciedlające emisje i pochłanianie w odniesieniu do kategorii rozliczania gruntów objętych omawianą regulacją, a w tym zakresie musi także zapewnić dokładność, kompletność, spójność, porównywalność i przejrzystość swoich rozliczeń i innych danych przekazywanych na podstawie rozporządzenia (art. 5 rozporządzenia LULUCF). Istotny jest wymóg, by nie dokonywać podwójnego liczenia emisji lub pochłaniania, tzn. by emisje i pochłanianie nie były rozliczane w więcej niż jednej kategorii rozliczania gruntów (art. 5 ust. 2 rozporządzenia LULUCF).

W odniesieniu do gruntów zalesionych i gruntów wylesionych należy rozliczać emisje i pochłanianie jako sumaryczne emisje i sumaryczne pochłanianie dla każdego roku w okresach od 2021 r. do 2025 r. i od 2026 r. do 2030 r. (art. 6 ust. 1 rozporządzenia LULUCF). Regułą jest również to, że każde państwo członkowskie winno rozliczać emisje i pochłanianie w odniesieniu do zarządzanych gruntów leśnych obliczone jako emisje i pochłanianie w okresach od 2021 r. do 2025 r. i od 2026 r. do 2030 r., pomniejszone o pięciokrotność poziomu referencyjnego dla lasów danego państwa członkowskiego (art. 8 ust. 1 rozporządzenia LULUCF). Natomiast, gdy wynik wspomnianego obliczenia jest ujemny w odniesieniu do poziomu referencyjnego dla lasów ${ }^{19}$ dla danego państwa członkowskiego, państwo to musi włączyć do swoich rozliczeń dotyczących zarządzanych gruntów leśnych „,całkowite pochłanianie netto w wysokości nie więcej niż pięciokrotność równowartości 3,5\% emisji tego państwa członkowskiego w roku bazowym lub okresie bazowym, jak określono w załączniku III", z wyjątkami wskazanymi w rozporządzeniu LULUCF (tj. pochłaniania netto $z$ rezerwuarów węgla, jakie stanowią martwe drewno oraz produkty z pozyskanego drewna, z wyjątkiem kategorii papieru, o której mowa w art. 9 ust. 1 lit. a, w kategorii rozliczania gruntów obejmującej zarządzane grunty leśne).

Poziom referencyjny dla lasów opierać się musi na kontynuacji praktyki zrównoważonej gospodarki leśnej udokumentowanej w okresie od 2000 do 2009 r. w odniesieniu do dynamicznych cech lasu powiązanych z wiekiem w lasach krajowych przy użyciu najlepszych dostępnych danych. Poziom ten musi także uwzględniać ,,przyszły wpływ dynamicznych cech lasu powiązanych z wiekiem, aby uniknąć nadmiernego ograniczania intensywności gospodarki leśnej jako podstawowego elementu praktyki zrównoważonej gospodarki leśnej,

19 „Poziom referencyjny dla lasów” oznacza według art. 3 ust. 1 pkt 7 rozporządzenia LULUCF szacunkowy poziom referencyjny dla lasów wyrażony w tonach ekwiwalentu $\mathrm{CO}_{2}$ rocznie, średni roczny poziom netto emisji lub pochłaniania pochodzących z zarządzanych gruntów leśnych na terytorium danego państwa członkowskiego w okresach do $2021 \mathrm{r}$. do 2025 r. oraz od 2026 r. do 2030 r. w oparciu o kryteria określone w tym rozporządzeniu. 
mając na celu utrzymanie lub wzmocnienie w perspektywie długoterminowej pochłaniaczy dwutlenku węgla" (art. 8 ust. 5 rozporządzenia LULUCF).

Istnieje jednak możliwość zastosowania mechanizmów „elastyczności” (art. 12 i art. 13 rozporządzenia LULUCF). W szczególności, jeżeli państwo członkowskie wykazuje pochłanianie netto z użytkowania gruntów i leśnictwa, może przekazać te ilości innym państwom członkowskim. Podobnie państwa członkowskie mogą kompensować braki w sektorze LULUCF, wykorzystując roczne limity emisji otrzymane na podstawie przepisów rozporządzenia nr 2018/842. Uwzględniono różną zdolność państw członkowskich do podjęcia działań.

Rozporządzenie LULUCF zakłada również zachowanie proporcji pozyskanego drewna wykorzystanego na produkty z niego oraz bioenergię, jaka miała miejsce w latach 2000-2009. Wprowadzono mechanizm rekompensacji ewentualnej emisji z zarządzanych gruntów leśnych w przypadku, gdyby kraj nie osiągnął wielkości pochłaniania równoważnej poziomowi odniesienia, a jego działanie opierało się wyłącznie na lesistości kraju członkowskiego (średniej lesistości dla okresu referencyjnego 2000-2009). Polsce przyznano limit rekompensacji na 10 lat (2021-2030) wynoszący $-22,5 \mathrm{mln} \mathrm{t} \mathrm{CO}_{2}$ eq jako całkowity maksymalny możliwy do wykorzystania limit w tym okresie, jednak rozliczenie bilansów dla zalesienia lub wylesienia oraz produktów z pozyskanego drewna ( $\mathrm{z}$ wyłączeniem papieru) nie będzie ograniczane ani limitem, ani poziomem odniesienia.

\section{Regulacje krajowe}

Zasada zrównoważonego rozwoju wyrażona została w art. 5 Konstytucji $\mathrm{RP}^{20}$. Na gruncie art. 74 Konstytucji RP ochrona środowiska jest obowiązkiem władz publicznych, są one zobowiązane prowadzić politykę zapewniającą bezpieczeństwo ekologiczne współczesnemu pokoleniu i przyszłym. Z kolei według art. 1 ustawy o lasach akt ten reguluje ,zasady zachowania, ochrony i powiększania zasobów leśnych oraz zasady gospodarki leśnej w powiązaniu z innymi elementami środowiska i z gospodarką narodową" ${ }^{21}$. W świetle przepisów wspomnianej ustawy gospodarka leśna winna być prowadzona zgodnie z zasadami powszechnej ochrony lasów, trwałości ich utrzymania, ciągłości i zrównoważonego wykorzystania wszystkich funkcji lasu oraz powiększania

${ }^{20}$ Konstytucja Rzeczypospolitej Polskiej z 2 kwietnia1997 r., Dz.U. poz. 483 ze zm., dalej jako: Konstytucja RP.

${ }^{21}$ Art. 1 pkt 1 ustawy o lasach z 28 września 1991 r., t.j. Dz.U. z 2018 r., poz. 2129 z późn. zm., dalej jako: ustawa o lasach. 
zasobów leśnych, a także z zasadami określonymi w ustawie o zachowaniu narodowego charakteru zasobów naturalnych, która zobowiązuje do gospodarowania zasobami ,zgodnie z zasadą zrównoważonego rozwoju w interesie dobra ogólnego".

Do wspomnianej zasady nawiązuje także definicja legalna „trwale zrównoważonej gospodarki leśnej”"22, która oznacza „działalność zmierzającą do ukształtowania struktury lasów i ich wykorzystania w sposób i w tempie zapewniającym trwałe zachowanie ich bogactwa biologicznego, wysokiej produkcyjności oraz potencjału regeneracyjnego, żywotności i zdolności do wypełniania, teraz i w przyszłości, wszystkich ważnych ochronnych, gospodarczych i socjalnych funkcji na poziomie lokalnym, narodowym i globalnym, bez szkody dla innych ekosystemów". Zdaje się zatem, że intencją ustawodawcy było nadanie największej wagi funkcjom ochronnym lasów ${ }^{23}$. W literaturze podaje się, że funkcje ochronne lasu wyrażają się m.in. w „korzystnym wpływie (...) na kształtowanie globalnego i lokalnego klimatu, skład atmosfery, regulacji obiegu wody w przyrodzie, przeciwdziałaniu powodziom, lawinom i osuwiskom, ochronie gleb przed erozją i krajobrazu przed stepowieniem, zachowaniu potencjału biologicznego wielkiej liczby gatunków i ekosystemów, a także różnorodności krajobrazu i lepszych warunków produkcji rolniczej"24.

Zatem ochrona klimatu w świetle ustawy o lasach może i powinna być realizowana $\mathrm{w}$ ramach funkcji ochronnych. W ustawie brakuje jednak bardziej skonkretyzowanych wymogów dotyczących realizacji funkcji ochronnych w dziedzinie ochrony klimatu. Rozwiązania takie zostały wypracowane w obowiązkowych w świetle rozporządzenia nr 2018/841 dokumentach, a także w praktyce. Zgodnie z rozporządzeniem LULUCF nałożyło na państwa członkowskie obowiązek przedłożenia Komisji krajowego planu rozliczania dla leśnictwa, w tym przedstawienia proponowanego poziomu referencyjnego dla lasów, do 31 grudnia 2018 r. - na okres od 2021 r. do 2025 r. oraz do 30 czerwca 2023 r. - na okres od 2026 r. do 2030 r. (art. 8 ust. 3 rozporządzenia LULUCF). Komisja w porozumieniu z wyznaczonymi przez państwa członkowskie ekspertami przeprowadzi „ocenę techniczną" planów przedłożonych przez te państwa, a w tym zweryfikuje, $w$ jakim zakresie proponowane poziomy referencyjne dla lasów ustalono zgodnie $\mathrm{z}$ wymogami rozporządzenia LULUCF (art. 8 ust. 6 rozporządzenia LULUCF).

${ }^{22}$ Art. 6 ust. 1 pkt. 1a ustawy o lasach; por. Ramowa Konwencja Narodów Zjednoczonych w sprawie zmian klimatu sporządzona w Nowym Jorku dnia 9 maja 1992 r., ratyfikowana przez Polskę ustawą z 16 czerwca 1994 r., Dz.U. z 1994 r. nr 53, poz. 1238.

${ }_{23}$ Por. K. Leśkiewicz, Prawne aspekty zarzadzania lasami Skarbu Państwa, Lublin 2019, s. 86 i 92

${ }^{24}$ P. Paschalis-Jakubowicz, Polskie leśnictwo w Unii Europejskiej, Warszawa 2004, s. 147. 
Polska przyjęła projekt Krajowego planu na rzecz energii i klimatu na lata 2021-2030 25, w którym deklaruje, że zamierza wykorzystać mechanizmy elastyczności przewidziane w rozporządzeniu $\mathrm{ESR}^{26}$, w szczególności mechanizm uregulowany w art. 7 LULUCF, a także dodatkową pulę jednostek powiększających roczny limit (art. 10 ust. 2) oraz mechanizm przenoszenia, pożyczania i transferowania jednostek AEA (art. 5). Dokument ten powołuje się na możliwość przenoszenia przez państwa członkowskie niewykorzystanej części własnego limitu na kolejne lata okresu rozliczeniowego, pożyczania części własnego limitu z przyszłych lat lub też nabywania jednostek od innych państw członkowskich. Polska zakłada wykorzystanie rezerwy bezpieczeństwa (art. 11), gdyby pozostałe mechanizmy elastyczności okazały się niewystarczające do pokrycia niedoboru AEA w latach 2026-2030. Maksymalna całkowita pula dla wszystkich państw członkowskich, które spełnią określone warunki, wynosi 105 mln ton $\mathrm{CO}_{2}$ ekw. Krajowy plan na rzecz energii i klimatu zakłada zatem wykorzystanie niemal wszystkich dostępnych mechanizmów dodatkowych, pozwalających na łagodzenie skutków ambitnych celów UE, lecz nie podejmuje najważniejszych zagadnień. Dokumentowi temu Komisja UE zarzuciła, że nie wskazuje środków służących rozwiązaniu problemu przewidywanej znaczącej różnicy w stosunku do celu na rok 2030, zakładającego emisję gazów cieplarnianych w Polsce na poziomie $-7 \%$ w porównaniu do roku $2005 \mathrm{w}$ odniesieniu do sektorów nieobjętych unijnym systemem handlu uprawnieniami do emisji ${ }^{27}$.

Najistotniejszym wyzwaniem dla leśnictwa jest wdrożenie takich działań, które doprowadzą do zwiększenia zdolności do retencji węgla w elementach ekosystemu leśnego. Przyjmuje się zwłaszcza, że użytkowanie zasobów drzewnych regulowane etatem użytkowania lasu jest pochodną potrzeb wynikających z celów hodowlanych i ochronnych lasu i ma zapewniać ciągłość produkcji możliwie dużej ilości drewna najlepszej jakości, natomiast wymiar pozyskania drewna z drzewostanów dojrzałych powinien uwzględniać ograniczenia wynikające

${ }^{25}$ Krajowy plan na rzecz energii i klimatu na lata 2021-2030 Założenia i cele oraz polityki i działania PROJEKT - w. 3.1 z 04.01.2019, https://www.gov.pl/documents/33372/436746/Projekt_ KPEiK_na_lata_2021-2030.pdf/aaefd8b3-0dff-3cdd-f016-b9c478b96ce1 [dostęp: 09.09.2019]; por. także Polityka energetyczna Polski, oraz Strategia Odpowiedzialnego Rozwoju do roku 2020 - z perspektywa do 2030 z $2017 \mathrm{r}$.

${ }^{26}$ Ibidem, s. 53.

${ }^{27}$ Por. Zalecenie Komisji UE z dnia 18 czerwca 2019 r. w sprawie projektu zintegrowanego krajowego planu w dziedzinie energii i klimatu w Polsce obejmujacego lata 2021-2030 (2019/C 297/21), Dz.U. UE C z dnia 3 września 2019 r.). Pkt 1 wspomnianego zalecenia nakazuje dostarczenie dodatkowych informacji na temat planowanych polityk i środków mających na celu rozwiązanie wskazanego problemu. Chodzi m.in. o uszczegółowienie informacji na temat dodatkowych środków, zwłaszcza w sektorach budownictwa, rolnictwa i użytkowania gruntów, zmiany użytkowania gruntów i leśnictwa, a także stosowania zasad rozliczania określonych w rozporządzeniu nr 2018/841. 
z realizacji funkcji ochronnych i socjalnych, stanu obecnej i przyszłej struktury gatunkowej i wiekowej lasu i stopnia jej zgodności z właściwościami siedliska ${ }^{28}$.

W tym względzie należy sięgnąć do przygotowanego już przez Polskę Krajowego Planu Rozliczeń dla Leśnictwa ${ }^{29}$, który dla celów wykonania zobowiązań krajowych określonych w rozporządzeniu LULUCF dokonał podziału lasów w oparciu o kryteria różnic w strukturze użytkowania, w intensywności użytkowania głównego, a także dostępności i wiarygodności danych dotyczących stanu lasów oraz prowadzonej w nich gospodarki leśnej, na tzw. dwie warstwy stratyfikacyjne: lasy państwowe w zarządzie Państwowego Gospodarstwa Leśnego Lasy Państwowe (dalej jako „PGL LP”; ok. 77\% lasów) oraz lasy poza zarządem PGL LP (tzw. „lasy pozostałe”, obejmujące lasy pozostałych form własności, w tym głównie własności prywatnej, pozostające w zarządzie parków narodowych, w Zasobie Własności Rolnej Skarbu Państwa, inne należące do Skarbu Państwa oraz gminne). W lasach pozostałych KPRL odnotowuje wyraźnie odmienny sposób prowadzenia gospodarki leśnej o niższych wskaźnikach użytkowania głównego w stosunku do lasów w zarządzie PGL Lasy Państwowe ${ }^{30}$.

Gdy chodzi o pozyskanie drewna w odniesieniu do poziomu referencyjnego, z początkiem 2010 r. udział pozyskania w użytkowaniu rębnym w lasach zarządzanych przez PGL Lasy Państwowe wynosił około 48\%, natomiast w lasach pozostałych - około $26 \%$. Opracowane prognozy wskazują, że udziały te w kolejnych okresach mogą się zwiększać - do około 58\% w Lasach Państwowych oraz do około 41\% w lasach pozostałych w okresie 2026-2030 31 . Obecnie, tj. od roku 2017, udział pozyskania w użytkowaniu rębnym w lasach zarządzanych przez PGL LP wynosi około 54\%, natomiast w lasach pozostałych - około 23\%. Opracowane prognozy wskazują, że udziały te w kolejnych okresach mogą się zwiększać - do około 59\% w Lasach Państwowych oraz do około 30\% w lasach pozostałych w latach 2026-203032.

Wartości średnie szacunkowe prognozowanego rocznego salda emisji i pochłaniania dla lasów w okresie 2021-2025, oszacowanego dla kategorii CRF 4.A.1 Grunty leśne pozostające gruntami leśnymi, wyniosą odpowiednio, biorąc pod uwagę scenariusz według poziomu referencyjnego $-33296 \mathrm{w} 2021 \mathrm{r}$., -31229 w 2022 r., -29329 w 2023 r., -27595 w 2024 r. i -25717 w 2025 r., co wg poziomu odniesienia daje -29433 ton ekwiwalentu $\mathrm{CO}_{2}$ rocznie (obliczono to w sposób przyjęty w ramach sekcji A załącznika IV rozporządzenia

\footnotetext{
${ }^{28}$ Ibidem, s. $17-18$.

${ }^{29}$ KPRL, s. 16-17.

${ }^{30}$ KPRL, s. 6.

${ }^{31}$ KPRL, s. 21.

${ }^{32}$ KPRL, s. 23.
} 
nr 2018/841) ${ }^{33}$. Dokument KPRL wskazuje również, że powierzchnia lasów według poziomu referencyjnego w całym okresie objętym analizami (2010-2030) nie ulegnie zmianie.

Warto także wspomnieć o długoletnim projekcie PGL LP pn. „Leśne Gospodarstwa Węglowe", który ma na celu sprawdzenie możliwości uzyskania zwiększonego pochłaniania dwutlenku węgla przez obszary leśne wskutek podjęcia dodatkowych działań gospodarczo-leśnych ${ }^{34}$.

Nie należy zapominać o roli biomasy leśnej, której źródłami na cele energetyczne są drewno okrągłe z lasu i zadrzewień oraz produkty uboczne z procesów przetwórstwa drzewnego. Biomasa leśna stanowi ok. 20\% biomasy wykorzystywanej na cele energetyczne. W zakresie rozliczania i raportowania emisji gazów cieplarnianych z biomasy leśnej użytkowanej na cele energetyczne, krajowy plan adaptacji do zmian kliamtu wskazuje, iż jest ona uwzględniona przy rozliczaniu i raportowaniu salda pochłaniania i emisji tych gazów w ramach kategorii gruntów leśnych. Emisje związane z biomasą leśną użytkowaną na cele energetyczne są raportowane i rozliczane jako efekt strat biomasy leśnej z gruntów leśnych. Podaje się także, że zwiększone użytkowanie biomasy leśnej do roku 2030 będzie miało wpływ na rozliczanie i raportowanie pochłaniania i emisji z kategorii gruntów leśnych, przy czym obecnie wpływ ten wymaga ustalenia ${ }^{35}$.

W okresie referencyjnym (2000-2009) w planowaniu urządzeniowym obowiązywała reguła, że określona planem urządzenia lasu suma zadań z zakresu użytkowania rębnego i przedrębnego jest wartością maksymalną, co oznaczało, że w przypadku zwiększonego użytkowania przedrębnego ograniczane było użytkowanie rębne. Wskazano, że przeciętne wieki rębności / okresy rotacji (w latach) dla najważniejszych gatunków drzew w lasach w zarządzie PGL LP kształtowały się następująco: sosna - 105, świerk - 95, buk - 115, dąb - 140, brzoza -80 , olcha -75 . KPRL podkreśla różnicę pomiędzy lasami w zarządzie PGL LP a lasami pozostałych form własności w zakresie planowania oraz realizacji obowiązujących planów urządzenia lasów.

W lasach zarządzanych przez PGL LP wielkość realizowanego łącznego użytkowania głównego w zasadzie w dużym stopniu pokrywała się z wielkością planowanego użytkowania głównego, zaś w lasach pozostałych - szczególnie w lasach prywatnych - realizacja zaplanowanych zadań była (podobnie jak obecnie) zdecydowanie mniejsza. Inne też były sposoby prowadzenia gospodarki

${ }_{33}$ KPRL, s. 45.

${ }^{34}$ Krajowy plan na rzecz energii $i$ klimatu na lata 2021-2030 Założenia i cele oraz polityki i dziatania PROJEKT - w. 3.1 z 04.01.2019, https://www.gov.pl/documents/33372/436746/ Projekt_KPEiK_na_lata_2021-2030.pdf/aaefd8b3-0dff-3cdd-f016-b9c478b96ce1, s. 55 [dostęp: 09.09.2019].

${ }^{35}$ Ibidem, s. 19. 
leśnej, które w lasach prywatnych bywają upraszczane i dopasowane do potrzeb ich właścicieli „w ramach użytkowania przedrębnego". Dlatego w praktyce zdecydowana większość pozyskania drewna w lasach prywatnych (szacowana na około 80\%) następuje w „użytkowaniu przedrębnym”, a znacznie mniejsza (około $20 \%$ pozyskanej miąższości) „w użytkowaniu rębnym”36. Wskazuje to na potrzebę doskonalenia regulacji prawnej oraz praktyk w zakresie gospodarki leśnej w lasach prywatnych.

\section{Podsumowanie}

Mechanizmy rozliczania emisji gazów cieplarnianych z użytkowania gruntów w taki sposób, by emisje były całkowicie równoważone pochłanianiem $\mathrm{CO}_{2} \mathrm{z}$ atmosfery poprzez działanie w sektorze leśnictwa są niezwykle złożone i mają wymiar interdyscyplinarny. Dotyczą one bowiem różnych obszarów, w tym leśnictwa, ekonomii i prawa. Stąd też dobre poznanie i zrozumienie reguł, którym zostały one podporządkowane wymaga konfrontancji różnych puntków widzenia, czego nie sposób uczynić w tej krótkiej publikacji. Przeprowadzone rozważania pokazują, że dla zbadania możliwych skutków wprowadzonych rozwiązań prawnych nie wystarczy jedynie ich analiza dogmatyczna. Zauważyć trzeba, że ocena efektów ekonomicznych nowej regulacji LULUCF czy skutków dla gospodarki leśnej na obecnym etapie jej wdrażania byłaby w najlepszym wypadku zwykłą prognozą.

Z prawnego punktu widzienia można jednak stwierdzić, że rozwiązania LULUCF istotnie ingerują w kompetencje państw członkowskich w sferze gospodarki leśnej, mimo że w świetle TFUE pozostawiono je w gestii tych państw. Konstruują wspólną politykę leśną w dziedzinie klimatu, a państwom członkowskim pozostawiono jedynie wykonanie założonych celów normatywnych. Rozporządzenie LULUCF w zakresie analizowanych mechanizmów rozliczeń emisji i pochłaniania gazów cieplarnianych w lasach może być zaliczone do aktów reglamentujących działalność w sferze użytkowania lasów.

Mechanizmy rozliczeń emisyjnych i pochłania $\mathrm{CO}_{2}$ bazują na danych historycznych w założeniach wyjściowych, a dążyć mają do zakładanych na przyszłość rezultatów. Badając sferę regulacyjną nie sposób przesądzić a priori, czy analizowana regulacja przyniesie określone korzyści, czy straty z perspektywy ekonomicznej w zakresie pozyskania drewna w lasach państwowych. Zależeć to będzie od wyniku rozliczenia emisji i pochłaniania. Nieprzekroczenie poziomu dozwolonych emisji gazów objętych regulacją nie musi oznaczać

\footnotetext{
${ }^{36}$ KPRL, s. 39.
} 
zmniejszenia ilości pozyskiwania drewna, a co za tym idzie - negatywnych skutków ekonomicznych. Chodzi bowiem o to, jaka będzie ilość uwolnionego $\mathrm{w}$ ten sposób $\mathrm{CO}_{2}$. Jeśli emisje będą wyższe niż zakładane, to istnieją możliwości kompensacji. Dopiero w przypadku przekroczenia poziomów emisji, mimo skorzystania także z dodatkowych mechanizmów bilansujących, skutkiem mogą być ograniczenia pozyskiwania drewna. W świetle rozporządzenia LULUCF pozytywnie ocenić można projekt „leśnych gospodarstw węglowych”, a także planowane zalesienia kraju. Rozwiązania i dane przyjęte w krajowym planie rozliczeń dla leśnictwa wskazywać mogą już dzisiaj, że regulacja rozporządzenia LULUCF nie musi być dla Polski niekorzystna, choć w istocie jej cele są bardzo ambitne.

\section{LEGAL ASPECTS OF INCLUSION OF GREENHOUSE GAS EMISSIONS AND REMOVALS RESULTING FROM ACTIVITIES RELATED TO LAND USE, LAND USE CHANGE AND FORESTRY}

\section{Summary}

The aim of the article is to assess whether the binding legal regulations, including the national ones, may be assessed as conducive to the achievement of the objectives of the EU's Energy Union in the scope of forest land management. In particular, whether the solutions adopted by Poland with regard to forest management may be considered as supporting the achievement of the objectives of the LULUCF regulation. The mechanisms of accounting for $\mathrm{CO} 2$ emissions and removals are based on historical data in the initial assumptions, and are intended to serve the implementation of the effects projected for the future. It is impossible to determine a priori whether the regulation in question will bring specific economic benefits or losses in terms of timber harvesting in state-owned forests. After all, it will depend on the result of accounting for emissions and removals from LULUCF.

\section{LE EMISSIONI E GLI ASSORBIMENTI DI GAS A EFFETTO SERRA DERIVANTI DALL'USO DEL SUOLO, DAL CAMBIAMENTO DI USO DEL SUOLO O DALLA SILVICOLTURA NELLA POLITICA CLIMATICA ED ENERGETICA: ASPETTI GIURIDICI}

\section{Riassunto}

L'articolo si propone di valutare se le regolazioni in vigore, compresa quella nazionale, risultino favorevoli al fine di realizzare gli obiettivi dell'Unione dell'energia nell'ambito forestale. Nello specifico, la domanda interessa le soluzioni adottate da parte della Polonia nel campo della gestione forestale finalizzate a garantire il raggiungimento degli obiettivi del 
regolamento LULUCF. Nelle ipotesi iniziali, i meccanismi di contabilizzazione delle emissioni e dell'assorbimento di $\mathrm{CO} 2$ si basano su dati storici, ma il loro intento è quello di raggiungere gli effetti prestabiliti per il futuro. Esaminando la sfera legislativa, è impossibile stabilire a priori, guardando da una prospettiva economica, se la regolazione in oggetto porterà o no a determinati benefici per quanto concerne il disboscamento delle foreste statali. Dopotutto, tutto dipenderà dal risultato della contabilizzazione. 